\title{
POLA PENGOBATAN PENDERITA SCHISTOSOMIASIS (PENYAKIT DEMAM KEONG) DI DESA KADUWAA KECAMATAN LORE UTARA KABUPATEN POSO PROPINSI SULAWESI TENGAH
}

\author{
Joni Tandi \\ Program Studi S1 Farmasi, STIFA Pelita Mas Palu \\ Corresponding author email : jonitandi757@yahoo.com
}

\begin{abstract}
ABSTRAK
Telah dilakukan penelitian Pola Pengobatan Penderita Schistosomiasis (Penyakit Demam Keong) di Desa Kaduwaa Kecamatan Lore Utara Kabupaten Poso Propinsi Sulawesi Tengah. Penelitian ini bertujuan untuk menanggulangi penyakit schistosomiasis ditinjau dari kerasionalan pengobatan untuk menanggulangi penyakit schistosomiasis dan untuk mengetahui perbedaan pola pengobatan penderita schistosomiasis di Kaduwa dan Napu keseluruhan, berdasarkan persentase penggunaan obat. Data diolah dan dideskripsikan terlebih dahulu kemudian dianalisis dengan uji chi kuadrat. Hasil pengujian menunjukkan bahwa tidak terdapat perbedaan pola pengobatan penderita schistosomiasis di Kaduwaa dan Napu keseluruhan. Petunjuk teknis Pengobatan Penderita Schistosomiasis (Penyakit demam Keong), penggunaan obat praziquantel menurut petunjuk teknis yaitu 60mg/Kg BB diminum dua kali setiap 4-6 jam sehari, dan terhadap efek samping telah digunakan paracetamol dan CTM.
\end{abstract}

Kata kunci : Praziquantel, pola pengobatan, chi square analisis

Submitted on: 8 November 2017 Accepted on: 1 Desember 2017

DOI: https://doi.org/10.25026/jsk.v1i9.74

\section{PENDAHULUAN}

Pertumbuhan ekonomi yang terus berkembang pesat pada dewasa ini mengakiibatkan berbagai dampak positif pada masyarakat. Penigkatan dalam bidang ksesehatan dan sarana kesehatan yang harus senantiasa didukung dan diperhatikan. Puskesmas adalah salah satu yang sangat dibutuhkan dalam kehidupan. Sarana ini berfungsi dalam kegiatan pelayanan kesehatan pada masyarakat. Pelayanan ini meliputi, memberikan penyuluhan kepada masyarakat tentang gizi, memberi masukkan dan klasifikasi untuk studi kelayakan pada masyarakat luas tentag keluarga, dan pengobatan. Pengobatan meliputi, elayani penyakit infeksi maupun penyakit menular dan berbagai penyakit lainnya seperti penyakit parasit.
Farmasi adalah ilmu yang mempelajari cara membuat, mencampur, meracik formulasi obat, identifikasi, kombinasi, analisis dan standarisasi/pembakuan obat serta pengobatan. Hal ini termasuk pula sifatsifat obat dan distribusinya serta penggunaannya yang aman. Ilmu resep adalah ilmu yang mempelajari tentang cara penyediaan obat-obatan menjadi bentuk tertentu (meracik) hingga siap digunakan sebagai oabt. Obat berperan sangat penting dalam ilmu kesehatan. Penanganan dan pencegahan berbagai macam penyait tidak dapat dilepaskan dari tindakan terapi dengan obat atau farmakoterapi. Berbagai pilihan obat saat ini tersedia, sehingga diperlukan pertimbangan-pertimbangan yang cermat dalam memilih obat untuk suatu penyakit. Sediaan ini harus selalu 
digunakan secara benar agar memberikan manfaat klinik yang optimal.

Antelmintik atau obat cacing ialah obat yang digunakan untuk memberantas atau mengurangi cacing dalam lumen usus atau jaringan tubuh. Kebanyakan obat cacing efektif terhadap satu macam cacing, sehingga diperlukan diagnosis tepat sebelum menggunakan obat tertentu. Antelmintik yaitu obat yang bertujuan untuk membasmi atau membunuh cacing.

Masalah penggunaan obat yang tidak rasional masih cukup menonjol di beberapa pusat pelayanan kesehatan. Hal ini berakibat pada pemborosan biaya, ketidakrasionalan penggunaan obat juga meningkatkan resiko terjadinya efek samping. Efek lainnya adalah brupa ketergantungan pasien terhadap pemberian yang selanjutnya secara luas akan meningkatkan resiko terjadinya resistensi. Penyebab lainnya akibat penggunaan antibiotik yang tidak tepat pada penduduk. Efek negatif penggunaan obat yang tidak rasional sangat beragam dan bervariasi tergantungdari jenis ketidakrasionalan penggunaannya.masalah ini dapat saja hanya dialami oleh pasien (efek sampig dan biaya yang mahal) maupun oleh penduduk yang lebih luas (resistensi kuman terhadap antibiotik tertentu) dan mutu pelayanan pengobatan secara umum.

Upaya mengatasi masalah penggunaan obat yang tidak rasional diperlukan. Perbaikan ini meliputi baik ditingkat provider yaitu pembuat resep (consumen) hingga sistem kebijakan obat nasional. Masih kurang tertatanya sistem informasi pengobatan dari tenaga kesehatan ke pasien menjadi salah satu masalah dalam proses terapi. Di satu sisi salah satu alasan tenaga kesehatan mengapa tidak rasional akibat tekanan dan permintaan pasien terhadap obat tertentu (misalnya penggunaan injeksi). Sementara itu di pihak pasien sebenarnya tidak pernah ada terhadap setiap proses pengobatan yang dilakukan oleh tenaga kesehatan.

Schistosomiasis atau disebut juga penyakit demam keong merupakan penyakit parasit yang disebabkan oleh infeksi cacing yang tergolong dalam genus schistosoma. Schistosoma japonicum dianggap cacing yang paling berbahaya dibandingkan schistosoma yang lain, karena jumlah telur yang dihasilkan paling banyak. Gejala yang ditimbulkan yaitu dmam, kulit tampak bengkak, gatal yang menyeluruh, gangguan perut kembung dll.

Berdasarkan latar belakang tersebut maka perlu mengadakan penelitian mengenai pola penggunaan obat schistosomiasis di desa Kaduwaa yang terekam datanya di Puskesmas Wuasa, dan laboratorium schistosomiasis.

bagaimanakah pola pengobatan schistosomiasis ditinjau dari kerasionalan pengobatan untuk menanggulangi penyakit schistosomiasis. Termasuk obat untuk mengobati gejala-gejala sampingan pada penggunaan obat anti schistosoma japonicum. (ii) apakah ada perbedaan pola pengobatan penderita schistosomiasis di Kaduwaa dan Napu keseluruhan.

Dalam penelitian ini agar diketahui kerasionalan terapi dan kesesuaian dengan standar pelayanan medik yang berlaku di Puskesmas Wuasa kecamatan Lore Utara kabupaten Poso Provinsi Sulawesi Tengah. Hasil penelitian ini diharapkan dapat memberikan manfaat pada tenaga kesehatan yang ada di Puskesmas Wuasa dan masyarakat serta lingkungan sekitar desa Kaduwaa dalam rangka meningkatkan mutu pelayanan kesehatan kepada masyarakat.

Data yang digunakan dalam penelitian berupa data sekunder tentang 
jumlah penderita shistosomiasisdan data restrospektif dengan penelusuran dokumen catatan rekam medik penggunaan obat penderita schistosomiasis. Data yang diperoleh dianalisis dengan menggunakan metode deskriptif sedangkan bagian pola pengobatan di desa Kaduwaa terhadap pola pengobatan di Napu dinyatakan dalam statistik chi kuadrat (chi square). Hasil persentase penelitian ditampilkan dalam bentuk tabel dan diagram untuk mengetahui gambaran obat pada penderita schistosomiasis di desa Kaduwaa kecamatan Lore Utara kabupaten Poso Provinsi Sulawesi Tengah.

\section{METODE PENELITIAN}

\section{Populasi dan Sampel}

\section{Populasi}

Populasi dalam penelitian ini adalah semua pasien di Napu yang menderita penyakit Schistosomiasis yang tercatat di Laboratorium Schistosomiasis dan Puskesmas Wuasa.

\section{Sampel}

Sampel dalam penelitian ini adalah ata rekam medik pasien yang menderita penyakit schistosomiasis yang tercatat di desa Kaduwaa.

\section{Tempat Penelitian}

Penelitian dilaksanakan di Puskesmas Wuasa Laboratorium Schistosomiasis di desa Kaduwaa kecamatan Lore Utara kabupaten Poso Provinsi Sulawesi Tengah.

\section{Izin Penelitian}

Penelitian diawali dengan perizinan dari kampus Sekolah Tinggi Ilmu Farmasi Pelita Mas Palu (STIFA-PM) melalui bagian penelitian dan persetujuan diberika oleh Kepala Dinas Kesehatan Kabupaten Poso dan Puskesmas Wuasa, serta penanggung jawab Laboratorium Schistosomiasis Wuasa kecamatan Lore Utara kabupaten Poso Provinsi Sulawesi Tengah.

\section{Prosedur Penelitian}

Penelitian dimulai dari pencatatan penderita schistosomiasis Wuasa kecamatan Lore Utara kabupaten Poso Provinsi Sulawesi Tengah. Pencatatan diambil dari dokumen rekam medik sejumlah 7 pasien meliputi diagnosa penyakit schistosomiasis, jenis kelamin, umur, dan catatan penggunaan obat. Setelah pencatatan dokumen rekam medik selanjutnya dilakukan wawancara dengan petugas yang terkait dilakukan untuk memperoleh informasi tambahan mengenai penyakit pasien. Selanjutnya data ditabulasi dan dilakukan analisis data lalu membahas dan menyimpulkan hasil penelitian.

\section{Analisis Data}

Berdasarkan data yang diperoleh, dilakukan :

1. Pengelompokkan data pasien berdasarkan jenis kelamin, umur, dan data pengobatan. (Dapat dilihat pada tabel 3)

2. Analisis rasionalitas penggunaan obat penderita schistosomiasis meliputi ketepatan dosi, ketepatan cara penggunaan obat di desa Kaduwaa Kecamatan Lore Utara kabupaten Poso Provinsi Sulawesi tengah tahun 2011. (Dapat dilihat pada tabel 4)

3. Analisis data dengan menggunakan chi kuadrat (chi square) untuk melihat ada tidaknya perbedaan penggunaan obat di desa Kaduwaa dan Napu keseluruhan. 
Pola Pengobatan Penderita Schistosomiasis (Penyakit Demam Keong) Di Desa Kaduwaa Kecamatan Lore Utara Kabupaten Poso Propinsi Sulawesi Tengah

\section{HASIL DAN PEMBAHASAN}

\section{Hasil Penelitian}

Tabel 1. Tabel Jumlah pemakaian Obat Pada Saat Pengobatan Massal di Napu dan di Kaduwaa tahun 2011

\begin{tabular}{ccccccc}
\hline \multirow{2}{*}{ No } & Nama & Jumlah yang & Jumlah & \multicolumn{3}{c}{ Jumlah Pemakaian Obat } \\
\cline { 6 - 7 } & Desa & yang & diobati & $\begin{array}{c}\text { Praziquantel } \\
\text { (Kaplet) }\end{array}$ & $\begin{array}{c}\text { Paracetamol } \\
\text { (Tablet) }\end{array}$ & $\begin{array}{c}\text { Klorfeniramin } \\
\text { Maleat (CTM) } \\
\text { (Tablet) }\end{array}$ \\
\hline 1 & Kaduwaa & 587 & 520 & 3.120 & 300 & 300 \\
2 & Napu & 15.397 & 12.585 & 77.436 & 6.325 & 5.375 \\
\hline
\end{tabular}

Tabel 2. Tabel Persentase Penggunaan Obat Schistosomiasis di Napu dan di Desa Kaduwaa

\begin{tabular}{cccc}
\hline \multirow{2}{*}{ No } & \multirow{2}{*}{ JENIS OBAT } & RATA-RATA DESA DI & \multicolumn{2}{c}{ DESA KADUWAA } \\
& & NAPU $(\%)$ & 88,58 \\
\hline 1 & Persentase Praziquantel & 83,50 & 6,40 \\
2 & Persentase Paracetamol & 5,58 & 6,40 \\
3 & Persentase CTM & 4,74 & \\
\hline
\end{tabular}

Sumber : Puskesmas Wuasa dan Laboratorium Schistosomiasis

Tabel 3. Pengelompokkan Data Pasien Schistosomiasis Berdasarkan Jenis Kelamin

\begin{tabular}{cccc}
\hline No & Jenis Kelamin & Jumlah & Persentase (\%) \\
\hline 1 & Laki-laki & 3 Pasien & $42,86 \%$ \\
2 & Perempuan & 4 Pasien & $57,14 \%$ \\
\hline & Jumlah & 7 Pasien & $100 \%$ \\
\hline
\end{tabular}

Tabel 4. Pengelompokkan Data Pasien Berdasarkan Usia

\begin{tabular}{cccc}
\hline No & Usia & Jumlah & Persentase \\
\hline 1 & 5-15 Tahun & 2 Pasien & $28,58 \%$ \\
2 & 16-26 Tahun & 1 Pasien & $14,28 \%$ \\
3 & $27-37$ Tahun & 2 Pasien & $28,58 \%$ \\
4 & 38-48 Tahun & 1 Pasien & $14,28 \%$ \\
5 & 49-59 Tahun & 1 Pasien & $14,28 \%$ \\
\hline
\end{tabular}

Sumber : Puskesmas Wuasa dan Rekam Medik Laboratorium Schistosomiasis Wuasa Tahun 2011

Tabel 5. Hasil Analisi Rasionalitas Penggunaan Obat Oleh Pasien Schistosomiasis

\begin{tabular}{|c|c|c|c|c|c|c|}
\hline \multirow[b]{2}{*}{ Rasionalitas Penggunaan Obat } & \multicolumn{3}{|c|}{ Gejala Klinis } & \multirow{2}{*}{$\begin{array}{l}\text { Jumlah } \\
\text { Psien }\end{array}$} & \multicolumn{2}{|c|}{ Rawat Jalan } \\
\hline & $\begin{array}{l}\text { Stadium } \\
\text { Invasti }\end{array}$ & $\begin{array}{l}\text { Stadium } \\
\text { Bertelur }\end{array}$ & $\begin{array}{l}\text { Stadium } \\
\text { Kronis }\end{array}$ & & Tepat & Tidak tepat \\
\hline $\begin{array}{l}\text { Ketepatan Obat } \\
\text { Ketepatan cara pemakaian obat: }\end{array}$ & 2 & 4 & 1 & 7 & 7 Pasien & 0 Pasien \\
\hline a. Ketepatan Dosis & 2 & 4 & 1 & 7 & 7 Pasien & 0 Pasien \\
\hline b. Ketepatan Frekuensi & 2 & 4 & 1 & 7 & 7 Pasien & 0 Pasien \\
\hline c. Ketepatan Lama Pemberian & 2 & 4 & 1 & 7 & 7 Pasien & 0 Pasien \\
\hline
\end{tabular}




\section{PEMBAHASAN}

Penelitian pola pengobatan penderita Schistosomiasis dan rekam medik Puskesmas Wuasa tahun 2013. Bedasarkan data sekunder yang dikumpulkan, diperoleh bahwa seluruh penduduk di desa Kaduwaa yang harus diobati berjumlah 587 penduduk, karena dilakukan pengobatan massal. Sedangkan yang diobati hanya berjumlah 520 penduduk. Hal ini disebabkan karena pada saat pengobatan massal dilakukan sebagian penduduk tidak diobati karena alasan-alasan tertentu misalnya hamil, tekanan darah terlalu tinggi dan alasan lain. Sehingga hanya $88,58 \%$ penduduk didesa Kaduwaa yang diobati. Dalam pengobatan tersebut penderita diberi tambahan obat Paracetamol dan CTM berdasarkan efek samping yang muncul, antara lain panas dan alergi.

Berdasarkan data sekunder pada tabel 1 jumlah pemakaian obat pada penderita Schistosomiasis di Napu dan di desa Kaduwaa Tahun 20011, kondisi tersebut sama seperti desa-desa lainnya di Napu secara keseluruhan dimana jumlah total penduduk yang harus diobati adalah 15.071 penduduk, sedangkan yang diobati hanya sebanyak 12.585 penduduk. Hal ini berarti hanya $83,50 \%$ penduduk yang diobati di Napu pada umumnya. Jumlah obat Praziquantel yang diberikan di desa Kaduwaa adalah 3.120 tablet, sedangkan di Napu keseluruhan adalah 77.436 tablet. Demikian juga pada obat Paracetamol di desa Kaduwaa hanya diberikan 300 tablet, sedangkan di Napu keseluruhan adalah 6.352 tablet, Begitu juga dengan obat CTM di desa Kaduwaa hanya diberikan sebanyak 300 tablet, sedangkan di Napu keseluruhan adalah 5.375 tablet.

Berdasarkan data sekunder yang terlihat pada tabel 2 persentase penggunaan obat Schistosomiasis di Napu dan di desa Kaduwaa adalah persentase obat Praziquantel adalah $83,50 \%$ sedangkan di desa Kaduwaa 88,58\%, persentase obat Paracetamol di Napu adalah 5,58\%, sedangkan di desa Kaduwaa adalah 6,40\%, persentase CTM di Napu adalah 4,74\% sedangkan di deesa Kaduwaa persentase CTM adalah 6,40\%.

Hasil identifikasi data yang dilakukan di Laboratorium Schistosomiasis Wuasa Kecamatan Lore Utara Kabupaten Poso Provinsi Sulawesi Tengah Tahun 2013, dengan subjek penelitian yaitu schistosomiasis tahun 2011 diperoleh data bahwa jumlah pasien yang terdiagnosa menderita schistosomiasis berjumlah 7 pasien. Pencatatan data tersebut diambil dari dokumen rekam medik pada pasien yang meliputi diagnosa penyakit schistosomiasis, jenis kelamin, umur pasien, catatan penggunaan obat dalam bentuk formulir pengobatan penderita penyakit schistosomiasis data diperoleh terebut kemudian dikelompokkan dalam beberapa bagian sesuai dengan karakteristik pasien yang meliputi jenis kelamin, umur pasien, dari usia anak-anak sampai usia lanjut. Selain itu menganalisis rasionalitas penggunaan obat pasien schistosomiasis meliputi ketepatan obat, ketepatan cara penggunaan obat (ketepatan dosis, ketepatan frekuensi, pemberian dan ketepatan lama pemberian) dan ketepatan penderita.

Berdasarkan identifikasi data yang telah dilakukan di Laboratorium Schistosomiasis Wuasa diperoleh data bahwa jumlah penderita schistosomiasis sebanyak 7 orang dengan jumlah pederita laki-laki 3 orang dan perempuan 4 orang. Dari hasil yang diperoleh menunjukkan bahwa jumlah persentase pasien schistosomiasis terbanyak berdasarkan 
jenis kelamin yaitu perempuan $57,14 \%$ dan laki-laki 42,86\% dapat dilihat pada tabel 3.

Berdasarkan data tersebut dapat diketahui bahwa jumlah penderita schistosomiasis terbanyak pada kelompok usia 5-15 tahun sebanyak 2 pasien $(28,58 \%), 27-37$ tahun sebanyak 2 pasien $(28,58 \%)$, dan kelompok terendah usia 1626 tahun sebanyak 1 pasien $(14,28 \%), 38$ 48 tahun sebanyak 1 pasien $(14,28 \%)$ dan 49-59 tahun sebanyak 1 pasien $(14,28 \%)$. Dapat dilihat pada tabel 4.

Dari hasil analisis rasionaltas penggunaan oabt oleh pasien penderita schistosomiasis dapat dilihat pada tabel 5, bahwa pada gejala klinis stadium invasi yaitu kelainan kulit dapat berupa eritema yang disertai perasaan gatal dan gatal ditempat serkaia masuk, gejala pertama timbul beberapa jam setelah infeksi, selanjutnya dapat terjadi alergi yang dapat timbul oleh adanya hasil metabolik schistosomula atau cacing dewasa dan dapat disertai demam, lemah, melaise, anoreksia, mual, muntah, sakit kepala dan nyeri tubuh, sakit perut karena diare (Pinardi Hadijaya, hal. 78). Pasien dengan usia yang berbeda, berumur 12 tahun dengan berat badan $30 \mathrm{Kg}$ dosis 1 Praziquantel diberikan $1 \frac{1}{2}$, dosis kedua 1 $1 / 2$ diminum sehari dengan jarak waktu 4-6 jam. Dan usia yang kedua yaitu umur 15 tahun dengan berat badan $35 \mathrm{Kg}$ dengan dosis 1 Praziquantel $13 / 4$, dosis kedua $13 / 4$ dengan jarak waktu 4-6 jam.

Obat efek samping yang diberikan yaitu Paracetamol dengan dosis $500 \mathrm{mg}$ untuk dewasa dan untuk anak 12 tahun diberikan dosis 240-360 mg. CTM $4 \mathrm{mg}$ dan Oralit, dengan jumlah obat untuk 3 hari pemakaian. Pada stadium bertelur yaitu stadium klinik kedua dimulai dengan perletakan telur pertama didalam darah dan dikeluarkannya telur melalui mukosa.
Keluhan yang terjadi pada stadium ini adalah demam, melaise, berat badan menurun. Pada stadium ini terdapat pasien dengan usia 26 tahun berat badan $65 \mathrm{Kg}$ dengan dosis I Praziquantel $31 / 4$ dan dosis II $3{ }^{1 /}$. Usia 35 tahun dengan berat badan $70 \mathrm{Kg}$ dengan dosis Praziquantel $3 \frac{3}{4}$ dan dosis II $33 / 4$, dan umur 48 tahun dengan berat badan $35 \mathrm{Kg}$ dosis I Praziquantel $13 / 4$ dan dosis II $1 \frac{3}{4}$. Dan usia 28 tahun dengan berat badan $45 \mathrm{Kg}$ dosis I Praziquantel 2 $1 / 4$, dosis II $2 \frac{1}{4}$, dengan jarak waktu 4-6 jam dalam sehari. Obat efek samping diberikan Paracetamol, CTM dan Vitamin B6. Untuk pemakaian 3 hari. Pada stadium kronis yaitu sakit perut, disentri dilatasi pembuluh darah abdomen, ikterus, udema, asites, hematemesis, anemia dan emasiasis. Usia 32 tahun dengan berat badan $70 \mathrm{Kg}$ dosis I $3 \frac{1}{2}$ dan dosis II $3 \frac{1}{2}$ dengan jarak waktu 4-6 jam dalam sehari. Obat efek samping yang diberikan yaitu Paracetamol, Vitamin B6, CTM dan Oralit, diberikan selama 3 hari pemakaian. Dengan pengertian bahwa pola pengobatan penderita schistosomiasis sudah rasional dilakukan didesa Kaduwaa dan desa-desa di Napu secara keseluruhan, karena sudah mengikuti aturan petunjuk teknis yang ada, yang dikeluarkan oleh Sub Direktorat Filariasis dan Schistosomiasis Direktorat P2B2 Ditjen PPM dan PLP Departemen Kesehatan RI. Pengobatan penyakit schistosomiasis di desa Kaduwaa menggunakan obat Praziquantel. Praziquantel bekerja dengan cara mengobati semua bentuk schistosomiasis dan infeksi cestoda seperti sisticercosis. Permeabilitas membran sel terhadap kalsium meningkat. Menyebabkan parasit mengalami kontraktur dan paralisis. Praziquantel mudah diabsorbsi pada pemberian oral dantersebar sampai ke cairan serebospinal. Kadar yang tinggi 
dapat dijumpai dalam empedu. Obat dimetabolisme secara oksidatif dengan sempurna menyebabkan waktu paruh menjadi pendek. Metabolit tidak aktif dan dikeluarkan melalui urin dan empedu (Mycek.mary J.2012)

Pengobatan schistosomiasis pada dasarnya adalah mengurangi dan mencegah ksakitan dan mengurangi sumber penular. Sebelum ditemukan obat yang efektif, bebagai jenis obat telah dipakai untuk mengurangi penderita schistosomiasis misalnya hycanthone, niridazole, amocante dan sebagainya. Obat-obat tersebut tidak efektif dan beberapa sangat toksik. Pada saat ini obat yang dipakai adalah Praziquantel (Sudomo M. 2008)

Praziquantel sangat efektif terhadap semua bentuk schistosomiasis, baik dalam fase akut kronik maupun yang sudah mengalami spelenomegali atau bahkan yang mengalami komplikasi lain. Obat tersebut sangat manjur dan efek samping ringandan hanya diperlukan I dosis yaitu $60 \mathrm{mg} / \mathrm{KgBB}$ yang dibagi dua dan diminum dalam tenggang waktu 4-6 jam (Tjay, tan Hon dan Rivaldy Kirana 2007). Praziquantel merupakan derivat Pirazino Isokulnolin, obat ini merupakan antelmintik berspektrum lebar efektif terhadap cestoda dan trematoda pada hewan dan manusia, Praziquantel berbentuk kristal tidak berwarna dan rasanya pahit. (Syarif et al 1927).

Berdasarkan analisis penelitian didapat analisis data untuk pola pengobatan schistosomiasis dengan memberikan obat Praziquantel yaitu pengobatan dilakukan dengan cara memberikan obat kepada pasien sesuai dosis yang sudah ditentukan sesuai dengan berat badan. Sasaran penduduk yang diberi pengobatan adalah penduduk yang positif telur cacing schistosoma (penderita), penderita yang gejala klinis positif dangan tinja positif pada pemeriksaan sebelumnya, anggota keluarga yang positif telur cacing schistosoma.

Disamping obat khusus Praziquantel disediakan juga obat umum untuk mengatasi reaksi samping yang mungkin timbul biasanya sakit kepala, pusing, mual, sakit perut, gatal-gatal/kelainan pada kulit. (petunjuk teknis pegobatan schistosomiasis). Obat umum yang digunakan untuk mengatsi reaksi samping adalah Paracetamol, CTM dan Vitamin B6. Paracetamol yang bekerja sebagai metabolit fanasatin dengan efek antipiretik, efek analgesik Paracetamol dan fanasetin dengan salisilat yaitu menghilangkan atau mengurangi nyeri ringan sampai sedang. Keduanya menurunkan suhu tubuh dengan mekanisme yang dijaga berdasarkan efek sentral seperti salisilat. Paracetamol diabsorbsi cepat dan sempurna sampai saluran cerna.

CTM adalah turunan akilamin yang merupakan antihistamin dengan indeks terapi cukup besar dengan efek samping dan toksisitas yang efektif rendah (Siswandono, 1995). Mekanisme kerja CTM adalah menghambat efek histamin pada pembuluh darah bronkis dan bermacam-macam efek polos, selain itu klorfeniramin maleat dapat merangsang walapun menghambat susunan saraf pusat (Tjay,2002,Siswandono 1995). Klorfeniramin maleat memberikan efek samping walaupun juga bersifat serius dan kadang-kadang hilang bila pengobatan diteruskan. Efek samping yang sring terjadi adalah sedatif, gangguan saluran cerna, mulut kering. Kontraindikasi dari klorfeniramin maleat ini menimbulkan aktivitas antikolinergik yang dapat memperburuk asma bronkial, retensi urin, glukoma, klorfeniramin memiliki interaksi 
alkohol, depresan saraf pusat, anti kolinergik (IONI,2001, Tjay,2002).

Berdasarkan penelitian lapangan yang telah dilakukan mengenai informasi lisan tentang pola pengobatan schstosomiasis masa lalu adalah perawatan dari penderita dirawat di rumah masingmasing. Pada masing-masing desa dicatat dalam satu daftar penderita schistosomiasis dalam bentuk formulir (tabel formulir terlampir). Penderita schistosomiasis an bukan dalam bentuk baku status pasien seperti yang terjadi di rumah sakit pada umumya. Sehingga saat ini masih banyak kekurangan dalam perawatan dan cara mengatasi penderita penyakit schistosomiasis yang berada di daerah lembah Napu dan Lindu. Akibatnya masih banyak yang mengalami penyakit schistosomiasis.

\section{KESIMPULAN}

Berdasarkan hasil penelitian yang dilakukan, diperoleh :

1. Obat-obat yang digunakan penderita schistosomiasis di desa Kaduwaa Kecamatan Lore Utara Kabupaten Poso Provinsi Sulawesi Tengah yaitu Praziquantel, Paracetamol, CTM dan Vitamin B6.

2. Pola pengobatan schistosomiasis yang ada di desa Kaduwaa sama seperti pola pengobatan schistosomiasis di Napu pada umunya, dimana jumlah penderita yang diobati di desa Kaduwaa 520 penduduk, dengan jumlah obat Praziquantel 3.120 tablet $(88,58 \%)$, Paracetamol 300 tablet (6,4\%), dan CTM 300 tablet $(6,4 \%)$, sedangkan Napu keseluruhan yaitu jumlah penderita yang diobati sebanyak 12.585 penduduk, dengan jumlah obat Praziquantel 77.436 tablet $(83,50 \%)$, Paracetamol 6.352 tablet
$(4,74 \%)$ dan CTM 5.375 tablet $(6,40 \%)$.

3. Pola pengobatan dilapangan sudah mengikuti peraturan petunjuk teknis yang ada, yang dikeluarkan oleh Sub Direktorat Filariasis dan Schistosomiasis Direktorat P2B2 Ditjen dan PLP Departemen Kesehatan RI, kemudian penggunaan formulir pencatatan/pelaporan yang belum maksimal.

\section{DAFTAR PUSTAKA}

[1]. Abdurrahmat F., 2005. Metodologi Penelitian dan Tehnik Penyusun Skripsi. Penerbit Rineka Cipta. Jakarta, Cetakan Pertama Jakarta, 2006.

[2]. David.,2011. Farmakologi-antelmintik diakses tanggal 09 september 2012.

[3]. Viridiana N.N. 2010. Laporan akhir. Peran Serta Masyarakat Dalam Pencegahan dan Pengobatan Schistosomiasis di dataran Tinggi Napu, Kabupaten Poso. Sulawesi tengah. Balai Litbang P2B2 Donggala.

[4]. Lumeno H., 1990. Habitat Siput Oncomelania hupensis lindoensis, Sebagai Salah Satu Sasaran Dalam Usaha Pengendalian Penyakit Schistosomiasis Di Sulawesi Tengah Disertai PSL IPB Bogor.

[5]. Anonim., 2011. Makalah-ParisitologiTrematode-darah-dan-jaringan-jaringan. Diakses 15 september 2012

[6]. Hadidjaja Pinardi. 1985. Schistosomiasis di Sulawesi tengah. Fakultas Kedokteran Universitas Indonesia. Jakarta

[7]. SubDirektorat Filariasis dan Schistosomiasis Direktorat P2B2 DitJen PPM PLP Departemen Kesehatan RI. 1989. Petunjuk Teknis Pemberantasan Schistosomiasis (penyakit demam keong). Jakarta

[8]. Soedarto,. 1992., Helmintologi Kedokteran. Penerbit Buku Kedokteran EGC. Jakarta

[9]. Gunawan Gan.S. 2007. Farmakologi Dan Terapi, Edisi 5. Departemen Farmakologi Dan Terapeutik Fakultas Kedokteran Universitas Kedokteran. Gaya Baru. Jakarta

[10]. Purwanto hadjasaputra dkk., 2002. Data Obat Indonesia. Penerbit grafidia Medi Press. Jakarta 
[11]. Mycek, mary J. Dkk., 2001. Farmakologi Ulasan Bergambar Edisi 2. Widya Medika. Jakarta

[12]. Ikatan sarjana farmasi Indonesia., 2008. Informasi Spesialite Obat Indonesia Volume 43. PT. Sejahtera Lestari Farma.

[13]. Ilahude, D. Herry. H. 1998. Parasitologi Kedokteran. Fakultas Kedokteran Universitas Indonesia. Jakarta

[14]. Tjay Hoan tan, dkk.,2007. Obat-obat Penting Khasiat, penggunaan, dan Efek-efek Sampingnya. Edisi ke Enam. PT. Elex media Komputindo. Jakarta

[15]. Nurwidayati A. 2007. Koleksi Referensi Schistosomiasis Di dataran Tinggi Lindu Kabupaten Donggala Sulawesi tengah Tahun 2007. Balai Litbang P2B2 Donggala

[16]. Infomatorium Obat Nasional Indonesia.,2000, Departemen Kesehatan Republik Indonesia Direktorat Jendral Pengawasan Obat dan makanan. 2000. Sagung seto.

[17]. Tandi, Joni.,2011. Buku Penuntun Mata Kuliah Farmasi Klinik 1. Sekolah Tinggi Ilmu Farmasi dan pengetahuan Alam Pelita Mas Palu
[18]. Miting T.I. Laporan Akhir Tahun 1998 s/d 2005 Bidang Pelayanan Kesehatan Health Care Management Spesialist. P.T Ardes Perdana Konsultan.

[19]. Anif, Mohamad., 204. Penggolongan Obat berdasarkan Khasiat dan penggunaan. Gadjah Mada University Press. Yogyakarta. 12-13

[20]. Tandi, Joni., 2011. Panduan Penyusun dan Penulisan Skripsi. STIFA PM Palu. Palu

[21]. Syamsuni., 2007. Ilmu resep. Penerbit Buku Kedokteran. Jakarta

[22]. Putu., 2010. 7 Kriteria Upaya Pengobatan Rasional di Puskesmas. Diakses Tanggal 10 maret 2013

[23]. Conover, W.J. 1980. Practical Non Parametric Statistics 2 ed, Texas Tech University, John Wiley and Sons. New York Chichester Brisbane Toronto. 189

[24]. Murray.R. Spiegel. 1961. Theory and Problems of Statistics, Schaum publishing. CO. New York. 201 